Abstracta Iranica Abstracta Iranica

Revue bibliographique pour le domaine irano-aryen

Volume 24 | 2003

Comptes rendus des publications de 2001

\title{
« Mūnes al-'oššāq-e Sohravardī va ta'tīir-e ān dar adabiyyāt-e fārsī ». Našr-e Dāneš, 18, 2 (1380/2001), pp. 5-16.
}

Ève Feuillebois-Piérunek

\section{(2) OpenEdition \\ 1 Journals}

Édition électronique

URL : http://journals.openedition.org/abstractairanica/34620

ISSN : 1961-960X

\section{Éditeur :}

CNRS (UMR 7528 Mondes iraniens et indiens), Éditions de l'IFRI

\section{Édition imprimée}

Date de publication : 15 mai 2003

ISSN : 0240-8910

\section{Référence électronique}

Ève Feuillebois-Piérunek, « « Mūnes al-'oššāq-e Sohravardī va ta'țīr-e ān dar adabiyyāt-e fārsī ». Našr-e Dāneš, 18, 2 (1380/2001), pp. 5-16. », Abstracta Iranica [En ligne], Volume 24 | 2003, document 205, mis en ligne le 05 janvier 2010, consulté le 25 septembre 2020. URL : http://journals.openedition.org/ abstractairanica/34620

Ce document a été généré automatiquement le 25 septembre 2020.

Tous droits réservés 
« Mūnes al-'oššāq-e Sohravardī va ta'tīir-e ān dar adabiyyāt-e fārsī ». Našr-e Dāneš, 18, 2 (1380/2001), pp. 5-16.

Ève Feuillebois-Piérunek

1 L'auteur étudie l'influence du traité symbolique de Yahyā Sohravardī sur quelques écrivains et poètes persans, en particulier dans l'ouvrage de 'Arabšāh Yazdī, composé en 781, Dastūr-e 'oššāq de Fattāḥī (m. 852) et Ḥosn va 'ešq de Fuḍūlī (m. 962).

INDEX

Thèmes : 11.1.1. Littérature persane classique

\section{AUTEURS}

ÈVE FEUILLEBOIS-PIÉRUNEK

Sorbonne Nouvelle - Paris III 